Check for updates

Cite this: RSC Adv., 2018, 8, 27157

\title{
Complex formation constant of ferric ion with Gly, Pro-Hyp and Gly-Pro-Hyp $\dagger$
}

\author{
Mingyu Zhi, ${ }^{a}$ Yanan Li, ${ }^{\mathrm{b}}$ Shella Permatasari Santoso, ${ }^{\mathrm{c}}$ Fangyuan Chen ${ }^{\mathrm{b}}$ \\ and Guangrong Huang (D) *b
}

The complexes of protein hydrolysates with iron ions may provide one solution for treating iron deficiency because they can work as iron absorption promoters. The chelating ability of some protein hydrolyzates is the key for their iron absorption promotion. Collagen is the most abundant protein in the nature, and collagen peptides are reported to have the ability to promote iron absorption. Collagen's basic tripeptide unit, i.e., glycine-proline-hydroxyproline (Gly-Pro-Hyp) and its digestion products, glycine (Gly) and proline-hydroxyproline (Pro-Hyp), have been studied against the ferric metal ion. The complexation abilities were determined potentiometrically at three different temperatures of $25^{\circ} \mathrm{C}, 37^{\circ} \mathrm{C}$, and $40{ }^{\circ} \mathrm{C}$. The ionic strength was maintained using $0.15 \mathrm{~mol} \mathrm{dm}^{-3} \mathrm{NaCl}$. Potentiometric data were refined using Hyperquad 2008, and the species distributions were simulated using HySS2009. The complexes of $\left[\mathrm{MA}_{x} \mathrm{H}_{y}\right]$, with $x=1$ to 3 and $y=-4$ to 2 , were refined from three ligands at different temperatures and in the $\mathrm{pH}$ range from 2 to 11 . The complex formation constant $(\log \beta)$ indicated that the complex of GlyPro-Hyp was the most stable followed by Pro-Hyp and Gly complexes. Thermodynamic analysis revealed that the formation of the complexes of $\left[\mathrm{MA}_{x} \mathrm{H}_{y}\right]$, with $x=1$ to 3 and $y=0$, was spontaneous since the $\Delta G$ value was negative; this means that Gly, Pro-Hyp and Gly-Pro-Hyp have good iron chelating abilities and therefore, they can act as promising iron absorption promoters. The thermodynamic properties of these complexes were also studied, and the base for the usage of these complexes was provided.

Received 4th June 2018

Accepted 16th July 2018

DOI: $10.1039 / c 8 r a 04763 d$

rsc.li/rsc-advances

\section{Introduction}

Iron is known as an essential nutrient for humans; it plays important roles in many cellular metabolism activities such as electron transport in ferredoxin and in other cytochrome systems and oxygen transport in haemoglobin and myoglobin. ${ }^{1}$ The deficiency of iron may lead to several adverse health effects such as iron deficiency anaemia (IDA), reduction of work capacity, impairment of immune responses, development delays in infants, and increase in maternal and infant mortalities. $^{2}$ Approximately 700 million people suffer from Fe deficiency in different degrees, many of whom are women, children and the elderly. ${ }^{3}$ The direct intake of free iron ions to overcome Fe deficiency may have negative impacts on human health. Free iron ions catalyze the generation of reactive oxygen species (ROS). ${ }^{4}$ ROS cause damage to many organs such as digestive

${ }^{a}$ Hangzhou Vocational \& Technical College, Hangzhou, Zhejiang Province 310018, China

${ }^{b}$ College of Life Sciences, China Jiliang University, Hangzhou, Zhejiang Province 310018, China. E-mail: grhuang@126.com

'Department of Chemical Engineering, Widya Mandala Catholic University Surabaya, Surabaya 60114, Indonesia

$\dagger$ Electronic supplementary information (ESI) available. See DOI: $10.1039 / \mathrm{c} 8 \mathrm{ra04763d}$ tract, liver, and heart. Some studies have shown that Fe chelate complexes can promote the absorption of $\mathrm{Fe}^{5-9}$ At the same time, Fe in the form of a stable chelate complex is less harmful to tissues as it does not produce ROS.

Collagen is the most abundant protein in nature; it exists in the skin and bones of animals. Collagen peptides have many bio-functions such as improving the health of skin and bones. ${ }^{10,11}$ Collagen peptides are also known for their antioxidant and antihypertensive activities. ${ }^{12,13}$ Furthermore, collagen peptides can promote $\mathrm{Fe}$ absorption due to their metal chelating ability. As clarified by some studies, Fe-collagen peptide complexes can be easily absorbed by the small intestine ${ }^{14}$ and Caco-2 cells. ${ }^{6}$ Although there are some studies about the complexes of collagen peptides with $\mathrm{Fe}$, still many details regarding chelation are not clear.

In this study, the complex formation of Fe with collagen's basic units was investigated. Collagen tri-peptide, namely, glycine-proline-hydroxyproline (Gly-Pro-Hyp) and its digestion products, namely, glycine (Gly) and proline-hydroxyproline (Pro-Hyp) were chosen as the ligands since they are the most common basic units of collagen..$^{15}$ To gain basic information and initial understanding of $\mathrm{Fe}$-collagen chelation, the complexation study of Fe and collagen peptides was conducted potentiometrically. The complex formation was studied at three 

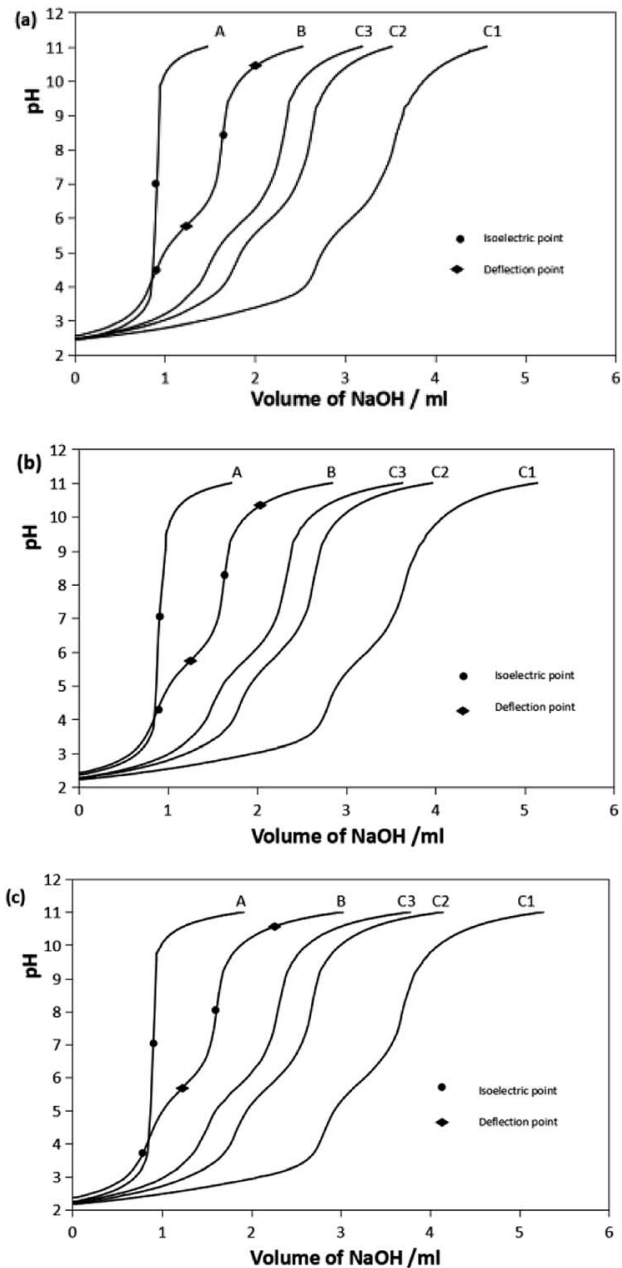

Fig. 1 Titration curves of Pro-Hyp with iron(III) at $I=0.15 \mathrm{~mol} \mathrm{dm}^{-3}$ $\mathrm{NaCl}$ and $25^{\circ} \mathrm{C}$ (a), $37^{\circ} \mathrm{C}$ (b) and $40{ }^{\circ} \mathrm{C}$ (c). Carbonate-free $\mathrm{NaOH}$ $\left(0.1 \mathrm{~mol} \mathrm{dm}^{-3}\right)$ was used to titrate the solutions. (A) $3 \times 10^{-3} \mathrm{~mol} \mathrm{dm}^{-3}$ $\mathrm{HCl}+0.15 \mathrm{~mol} \mathrm{dm}{ }^{-3} \mathrm{NaCl}$; (B) $3 \times 10^{-3} \mathrm{~mol} \mathrm{dm}{ }^{-3} \mathrm{HCl}+0.15 \mathrm{~mol}$ $\mathrm{dm}^{-3} \mathrm{NaCl}+3 \times 10^{-3} \mathrm{mmol} \mathrm{dm}{ }^{-3}$ Pro-Hyp; and (C) $3 \times 10^{-3} \mathrm{~mol}$ $\mathrm{dm}^{-3} \mathrm{HCl}+0.15 \mathrm{~mol} \mathrm{dm}^{-3} \mathrm{NaCl}+3 \times 10^{-3} \mathrm{mmol} \mathrm{dm}^{-3}$ Pro-Hyp +3 $\times 10^{-3}(\mathrm{C} 1), 1.5 \times 10^{-3}$ (C2) or $1 \times 10^{-3}$ (C3) $\mathrm{mol} \mathrm{dm}^{-3}$ ferric ions. Also, the solutions $\mathrm{C} 1, \mathrm{C} 2$ and $\mathrm{C} 3$ had molar concentration ratios of metal to ligand as $1: 1,1: 2$ and $1: 3$, respectively.

different temperatures, and the ionic strength was maintained with $0.15 \mathrm{~mol} \mathrm{dm}{ }^{-3} \mathrm{NaCl}^{\mathbf{. 6 , 1 7}}$ The three temperatures of $25{ }^{\circ} \mathrm{C}$, $37^{\circ} \mathrm{C}$, and $40{ }^{\circ} \mathrm{C}$ were chosen since they are the standard room temperature, normal body temperature, and fever temperature, respectively. The stabilities of the complexes were presented as the complex formation constants $(\log \beta)$. The distributions of the complex species in the $\mathrm{pH}$ range of $2-11$ are shown as species distribution diagram. Thermodynamic properties such as Gibbs energy $(\Delta G)$, enthalpy $(\Delta H)$ and entropy $(\Delta S)$ were also determined.

\section{Experimental}

\section{Materials and solutions}

Pro-Hyp $\left(\mathrm{C}_{10} \mathrm{H}_{16} \mathrm{~N}_{2} \mathrm{O}_{4}, \quad>98 \%\right.$ purity $)$ and Gly-Pro-Hyp $\left(\mathrm{C}_{12} \mathrm{H}_{19} \mathrm{~N}_{3} \mathrm{O}_{5},>98 \%\right.$ purity) were synthesized by Anhui Guoping Pharmaceutical Co., Ltd., China. Gly $\left(\mathrm{C}_{2} \mathrm{H}_{5} \mathrm{NO}_{2}\right.$, 99.5-
(1)<smiles>NCC(=O)[O-]</smiles>

(2)

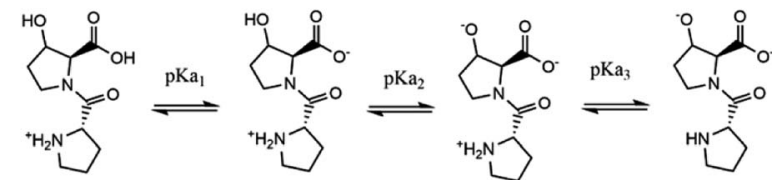

(3)

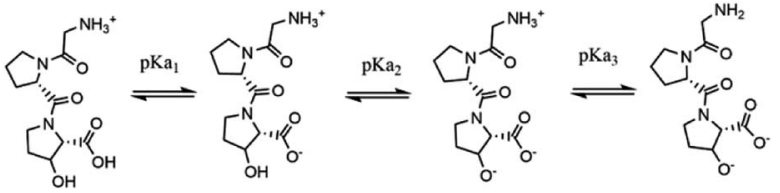

Scheme 1 Stepwise deprotonation of (1) Gly, (2) Pro-Hyp and (3) GlyPro-Hyp.

100.5\% purity), hydrochloric acid ( $\mathrm{HCl}, 37.6 \%$ purity), sodium chloride ( $\mathrm{NaCl}, 99 \%$ purity) and Ferric chloride $\left(\mathrm{FeCl}_{3}, 99 \%\right.$ purity) were purchased from Mick Chemical Instruments Co., Ltd., China. Sodium hydroxide (NaOH, 99\% purity) was provided by Tianjin Guangfu Fine Chemical Research Institute, China. All chemicals were of analytical grade and were used directly without further purification.

\section{Potentiometry measurement}

Potentiometric studies were conducted following the Hamed's method $^{\mathbf{1 8}}$ with a slight modification by using carbonate-free $\mathrm{NaOH}\left(0.1 \mathrm{~mol} \mathrm{dm}^{-3}\right)$ as the titrant against the following solutions:

(A) $3 \times 10^{-3} \mathrm{~mol} \mathrm{dm}^{-3} \mathrm{HCl}+0.15 \mathrm{~mol} \mathrm{dm}^{-3} \mathrm{NaCl}$.

(B) $3 \times 10^{-3} \mathrm{~mol} \mathrm{dm}^{-3} \mathrm{HCl}+0.15 \mathrm{~mol} \mathrm{dm}^{-3} \mathrm{NaCl}+3 \times$ $10^{-3} \mathrm{mmol} \mathrm{dm}^{-3}$ ligands (Gly, Pro-Hyp or Gly-Pro-Hyp).

(C1) $3 \times 10^{-3} \mathrm{~mol} \mathrm{dm}^{-3} \mathrm{HCl}+0.15 \mathrm{~mol} \mathrm{dm}^{-3} \mathrm{NaCl}+3 \times$ $10^{-3} \mathrm{mmol} \mathrm{dm} \mathrm{dm}^{-3}$ ligands (Gly, Pro-Hyp or Gly-Pro-Hyp) + $3 \mathrm{mmol} \mathrm{dm}^{-3}$ ferric ion.

(C2) $3 \times 10^{-3} \mathrm{~mol} \mathrm{dm}{ }^{-3} \mathrm{HCl}+0.15 \mathrm{~mol} \mathrm{dm}^{-3} \mathrm{NaCl}+3 \times$ $10^{-3} \mathrm{mmol} \mathrm{dm}{ }^{-3}$ ligands (Gly, Pro-Hyp or Gly-Pro-Hyp) $+1.5 \times$ $10^{-3} \mathrm{~mol} \mathrm{dm}^{-3}$ ferric ion.

(C3) $3 \times 10^{-3} \mathrm{~mol} \mathrm{dm}{ }^{-3} \mathrm{HCl}+0.15 \mathrm{~mol} \mathrm{dm}{ }^{-3} \mathrm{NaCl}+3 \times$ $10^{-3} \mathrm{~mol} \mathrm{dm}{ }^{-3}$ ligands (Gly, Pro-Hyp or Gly-Pro-Hyp) $+1 \times$ $10^{-3} \mathrm{~mol} \mathrm{dm}^{-3}$ ferric ion.

All solutions were freshly prepared in deionized (DI) water (>18.2 $\mathrm{M} \Omega \mathrm{cm}^{-1}$ resistance). The solution of $3 \times 10^{-3} \mathrm{~mol} \mathrm{dm}^{-3}$ $\mathrm{HCl}$ was used to acidify the solutions; $0.15 \mathrm{~mol} \mathrm{dm}{ }^{-3} \mathrm{NaCl}$ was used to maintain the ionic strength. The temperature was maintained by a circulating water bath $\left( \pm 0.1{ }^{\circ} \mathrm{C}\right)$, and three different temperatures of $25{ }^{\circ} \mathrm{C}, 37{ }^{\circ} \mathrm{C}$, and $40{ }^{\circ} \mathrm{C}$ were used. Potentiometric measurements were obtained using Metrohm 916 Ti-Touch with a pH-glass electrode (3 decimals readability). All measurements were done in triplicate.

The Hyperquad 2008 program $^{\mathbf{1 9}}$ was used to compute the protonation constants and the complex formation constants. The Hyperquad 2008 program is more simple and accurate in determining the complex formation constant compared to several non-linear-square algorithm computer programs. ${ }^{16}$ The refined formation constants of each complex species at 
Table 1 The $\mathrm{p} K_{\mathrm{a}}$ values of Gly, Pro-Hyp and Gly-Pro-Hyp at $I=0.15 \mathrm{~mol} \mathrm{dm}^{-3} \mathrm{NaCl}$ at three different temperatures ${ }^{a}$

\begin{tabular}{|c|c|c|c|c|c|c|c|c|}
\hline$T\left({ }^{\circ} \mathrm{C}\right)$ & \multicolumn{2}{|l|}{ Gly } & \multicolumn{3}{|l|}{ Pro-Hyp } & \multicolumn{3}{|c|}{ Gly-Pro-Hyp } \\
\hline 37 & $<2$ & $9.37(1)$ & $<2$ & $5.44(4)$ & $10.51(4)$ & $<2$ & $3.07(9)$ & $7.25(5)$ \\
\hline 40 & $<2$ & $9.27(2)$ & $<2$ & $5.23(5)$ & $10.36(5)$ & $<2$ & $2.71(13)$ & $7.18(5)$ \\
\hline
\end{tabular}

${ }^{a}$ Values in the parentheses indicate the standard deviation of the last decimal place; $\pm 95 \%$ confidence interval.

different temperatures were introduced to the HySS2009 program. ${ }^{20}$ HySS2009 was used to obtain the speciation diagrams that could be used to depict the distributions of various complex species in the observed $\mathrm{pH}$ ranges and at different temperatures. Thermodynamic properties such as Gibbs energy $(\Delta G)$, enthalpy $(\Delta H)$ and entropy $(\Delta S)$ were also determined. $\Delta G$ was calculated using eqn (1):

$$
\Delta G=-2.303 R T \log _{10} \beta
$$

$\Delta H$ and $\Delta S$ for each species were determined as the slope and the intercept of the Van't Hoff plot, respectively, as defined in eqn (2):

$$
\log _{10} \beta=\frac{\left(\frac{-\Delta H}{2.3033 R}\right) 1}{T}+\left(\frac{-\Delta S}{2.3033 R}\right)
$$

\section{Results and discussion}

\section{Protonation constants}

The representative titration curves of the Pro-Hyp system with trivalent ferric ions, $\mathrm{Fe}(\mathrm{III})$, at metal-to-ligand ratios of $1: 1$, $1: 2,1: 3$ are presented in Fig. 1 . The titration curves of Gly and Gly-Pro-Hyp systems are given as ESI, Fig. S1.† In all the systems, the Fe-ligand curve shifted to lower $\mathrm{pH}$ compared to the curve of the ligand alone, which indicated the formation of the chelate complex. The curves shifted more to the left as more $\mathrm{Fe}(\mathrm{III})$ ions were added, which means that the amount of the formed chelate complex increased since there were more Fe(III) ions available.

The B curves show the deprotonation of the ligand. The $\mathrm{pH}$ slowly increased as the titrant was gradually added into the solution until the isoelectric point was reached. At the isoelectric point, the $\mathrm{pH}$ increased sharply. The isoelectric point occurred between the 2 deflection points of the titration curve. These 2 points indicated the $\mathrm{pH}$ at which deprotonation occurred. Pro-Hyp and Gly-Pro-Hyp ligands exhibited more isoelectric points than Gly, indicating that they have more deprotonable functional groups.

The stepwise deprotonation of the three ligands is depicted in Scheme 1. Gly is a diprotic ligand with two functional groups, viz., carboxylic group $(-\mathrm{COOH})$ and amino group $\left(-\mathrm{NH}_{2}\right)$. Pro-Hyp and Gly-Pro-Hyp are triprotic ligands, and their functional groups are similar to those of Gly; they also have a third functional group, i.e., the hydroxyl group $(-\mathrm{OH})$. The first isoelectric point indicates the first deprotonation ( $\left.\mathrm{p} K_{\mathrm{a} 1}\right)$ for Gly, Pro-Hyp and Gly-Pro-Hyp, corresponding to the deprotonation of the $-\mathrm{COOH}$ group. The second deprotonation $\left(\mathrm{p} K_{\mathrm{a} 2}\right)$ indicated by the second isoelectric point for all the ligands corresponds to the deprotonation of the $-\mathrm{NH}_{2}$ group. Meanwhile, $\mathrm{p} K_{\mathrm{a} 3}$ values of Pro-Hyp and Gly-Pro-Hyp are observed due to the deprotonation of the $-\mathrm{OH}$ group.

Table 2 The $\log \beta$ values of Gly, Pro-Hyp and Gly-Pro-Hyp with iron(III) at $I=0.15 \mathrm{~mol} \mathrm{dm}{ }^{-3} \mathrm{NaCl}$ and $25^{\circ} \mathrm{C}, 37^{\circ} \mathrm{C}$ and $40{ }^{\circ} \mathrm{C}^{a}$

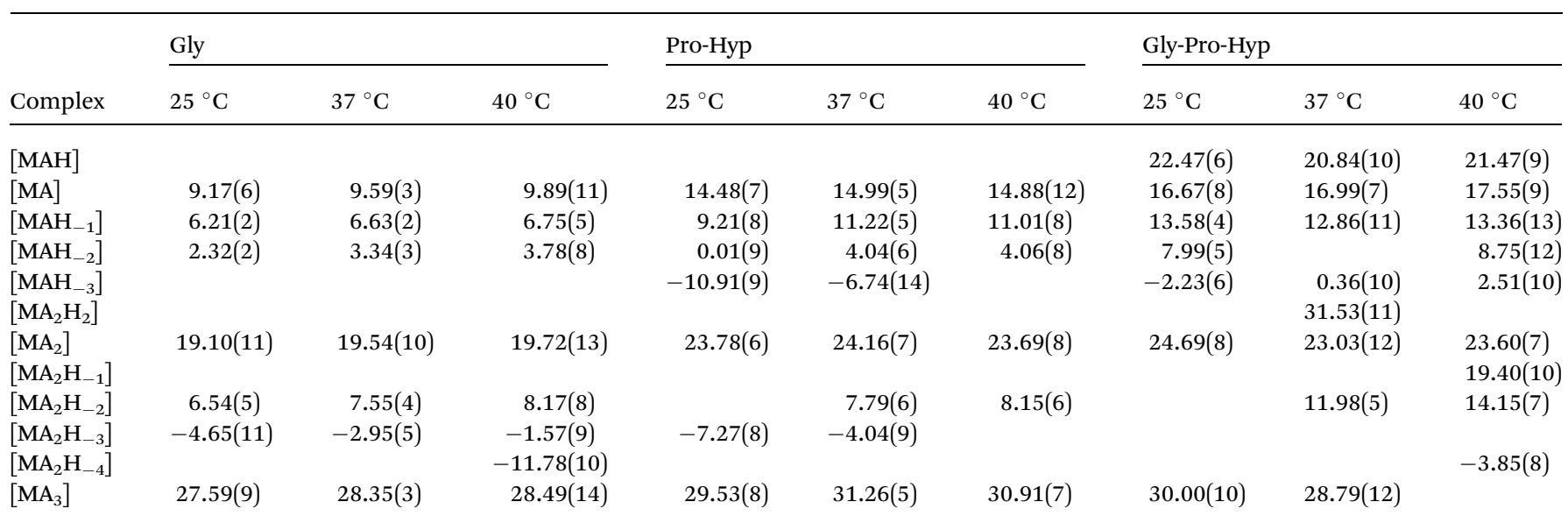

${ }^{a}$ The charge of each species is omitted for simplification. $\mathrm{M}$ indicates the Fe(III) ion, A indicates the ligand Gly or Pro-Hyp or Gly-Pro-Hyp, $\mathrm{H}$ indicates the proton, the negative value of $\mathrm{H}$ indicates the hydroxide ion. Values in the parentheses indicate the standard deviation of the last decimal place; $\pm 95 \%$ confidence interval. 

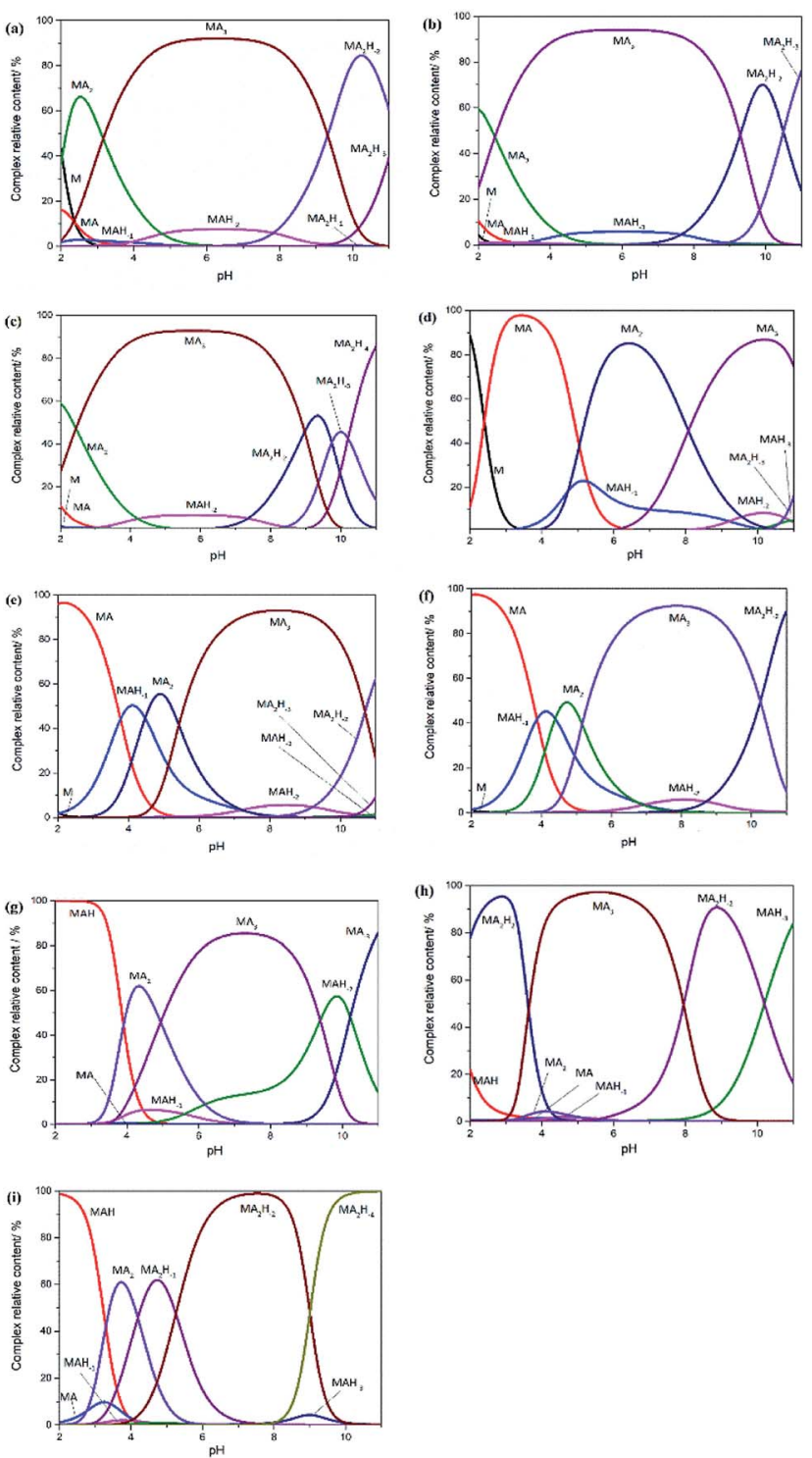

Fig. 2 Distribution of complexes of Gly, Pro-Hyp and Gly-Pro-Hyp chelates with iron(III) at $I=0.15 \mathrm{~mol} \mathrm{dm}^{-3} \mathrm{NaCl}$ and $25^{\circ} \mathrm{C}, 37^{\circ} \mathrm{C}$ and $40{ }^{\circ} \mathrm{C}$. (a) - (c) are the distributions of Gly complexes at the temperatures of $25^{\circ} \mathrm{C}, 37^{\circ} \mathrm{C}$ and $40^{\circ} \mathrm{C}$. (d) - (f) are the distributions of Pro-Hyp complexes at the temperatures of $25^{\circ} \mathrm{C}, 37^{\circ} \mathrm{C}$ and $40^{\circ} \mathrm{C}$. (g)-(i) are the distributions of Gly-Pro-Hyp complexes at the temperatures of $25^{\circ} \mathrm{C}, 37^{\circ} \mathrm{C}$ and $40^{\circ} \mathrm{C}$.

The Hyperquad 2008 program was used to determine the protonation constants of the ligands. The values for the protonation constants of the three ligands are presented in Table 1. $\mathrm{p} K_{\mathrm{a}}$ of the ligands indicates the $\mathrm{pH}$ at which $50 \%$ of the ligand deprotonated species is formed. The values of $\mathrm{p} K_{\mathrm{a} 1}(2.51$ $\pm 0.07)$ and $\mathrm{p} K_{\mathrm{a} 2}(9.68 \pm 0.03)$ of Gly at $25{ }^{\circ} \mathrm{C}$ were in a good agreement with the reported values of 2.33 and 9.61 (at $298.15 \mathrm{~K}$ and $0.05 \mathrm{M}$ ) by Gergely et $a .^{21}$ as well as 2.32 and 9.62 (at 298.15 $\mathrm{K}$ and $0.15 \mathrm{~mol} \mathrm{dm}{ }^{-3} \mathrm{NaNO}_{3}$ ) by Angkawijaya et al. ${ }^{22}$ The slight difference between the $\mathrm{p} K_{\mathrm{a}}$ values may be due to the use of different salts and ionic strengths.

The $\mathrm{p} K_{\mathrm{a} 1}$ values of Pro-Hyp and Gly-Pro-Hyp at $37{ }^{\circ} \mathrm{C}$ and $40{ }^{\circ} \mathrm{C}$ were lower than 2 ; thus, they could not be determined due to the accuracy limit of the potentiometric method. This was in accordance with the results reported by Zhu et al., where $\mathrm{p} K_{\mathrm{a} 1}$ of Pro was found to be $1.99 .{ }^{23}$ Similarly, $\mathrm{p} K_{\mathrm{a} 3}$ of Pro-Hyp at $25{ }^{\circ} \mathrm{C}$ was higher than 12 and could not be determined potentiometrically. The $\mathrm{p} K_{\mathrm{a} 1}$ values of Pro-Hyp and Gly-Pro-Hyp were lower than the $\mathrm{p} K_{\mathrm{a} 1}$ value of Gly; this indicated that the deprotonation of $-\mathrm{COOH}$ was triggered by the presence of imino group and other neighboring groups. The $\mathrm{p} K_{\mathrm{a} 3}$ value of Gly-ProHyp was lower than the $\mathrm{p} K_{\mathrm{a} 2}$ value of Gly, which was also due to the electron receptor effect of the imino group. All $\mathrm{p} K_{\mathrm{a}}$ values of the three ligands decreased as the temperature was increased, indicating that deprotonation was more favourable at a higher temperature; this was similar to the observation where $\mathrm{p} K_{\mathrm{a}}(\mathrm{pH})$ of $\mathrm{H}_{2} \mathrm{O}$ decreased as the temperature increased.

\section{Stability constant of the ferric complex}

The value of the complex formation constant $(\log \beta)$ can be used to indicate the stability of the complex; as the value of $\log \beta$ increases, the stability of the complex increases. The $\log \beta$ values of $\mathrm{Fe}(\mathrm{III})$ with Gly, Pro-Hyp, or Gly-Pro-Hyp were refined from three different metal-to-ligand ratios. According to the refinement of the potentiometric results by the Hyperquad 2008 program, various complex species of $\left[\mathrm{MA}_{x}\right]$ and $\left[\mathrm{MA}_{x} \mathrm{H}_{y}\right]$ were formed. The $\log \beta$ values of the complexes at $I=0.15 \mathrm{~mol} \mathrm{dm}^{-3}$ $\mathrm{NaCl}$ and at three different temperatures are shown in Table 2.

All the ligands could form chelate complexes with iron at a wide $\mathrm{pH}$ range and different temperatures. As shown by the $\log \beta$ values in Table 2 , the complexes of $\left[\mathrm{MA}_{3}\right],\left[\mathrm{MA}_{2}\right],[\mathrm{MA}]$ and $[\mathrm{MAH}]$ were found to be the most stable species compared with the complexes that contained hydroxide ions. This result was in accordance with another result reported previously: in the study conducted by Yakubov et al., the iron complexes with Gly, DiGly, and Tri-Gly had higher $\log \beta$ values compared to the complex containing $-\mathrm{OH} .{ }^{24}$ The $\left[\mathrm{MA}_{3}\right]$ complex had the highest $\log \beta$ value among all the ligands, indicating that this species was more stable than the other species. This result was similar to the results reported by Angkawijaya et al. and Fazary et al., which stated that the $\left[\mathrm{MA}_{3}\right]$ complex of $\mathrm{Fe}(\mathrm{III})$ with a ligand, namely, ferulic acid, L-norleucine or gallic acid had the highest stability constant value and thus, it was a stable species. ${ }^{25,26}$ However, an exception was observed for the $\log \beta$ value of $\left[\mathrm{MA}_{3}\right]$ with Gly-Pro-Hyp as the ligand, especially at the temperatures of $37{ }^{\circ} \mathrm{C}$ and $40{ }^{\circ} \mathrm{C} ;\left[\mathrm{MA}_{2} \mathrm{H}_{2}\right]$ was found to be more stable than $\left[\mathrm{MA}_{3}\right]$. This might be due to the steric hindrance effect of GlyPro-Hyp, which was larger than those of Gly and Pro-Hyp; this inhibited the formation of the $\left[\mathrm{MA}_{3}\right]$ complex, especially at higher temperatures. Gly-Pro-Hyp can chelate stably with iron, and two Gly-Pro-Hyps can also form a stable complex with a ferric ion. However three Gly-Pro-Hyps are sometimes not acceptable in a complex. The $\left[\mathrm{MA}_{3}\right]$ complex formed by Gly-ProHyp was unstable, especially at a high temperature. This may be because Gly-Pro-Hyp was too large to form a stable $\left[\mathrm{MA}_{3}\right]$ complex, which is similar to the observation where DL-2-(2-carboxymethyl)nitrilotriacetic acid (GLDA) and 3-hydroxy-2,2'-iminodisuccinic acid (HIDS) prefer to form $\left[\mathrm{MA}_{2} \mathrm{H}_{-1}\right]$ and $\left[\mathrm{MA}_{2} \mathrm{H}_{-2}\right]$ at $I=0.1$ and $1.0 \mathrm{~mol} \mathrm{dm}^{-3}$ at $25 \pm 0.1{ }^{\circ} \mathrm{C}$ (ref. 27) 
Table 3 Thermodynamic properties of Gly, Pro-Hyp and Gly-Pro-Hyp complexes of iron(III) at $I=0.15 \mathrm{~mol} \mathrm{dm}^{-3} \mathrm{NaCl}^{a}$

\begin{tabular}{|c|c|c|c|c|c|c|c|c|c|c|c|c|c|c|c|}
\hline \multirow{2}{*}{ Complex } & \multicolumn{5}{|l|}{ Gly } & \multicolumn{5}{|c|}{ Pro-Hyp } & \multicolumn{5}{|c|}{ Gly-Pro-Hyp } \\
\hline & \multicolumn{3}{|l|}{$-\Delta G$} & $\Delta H$ & $\Delta S$ & \multicolumn{3}{|l|}{$-\Delta G$} & $\Delta H$ & $\Delta S$ & \multicolumn{3}{|l|}{$-\Delta G$} & $\Delta H$ & $\Delta S$ \\
\hline$[\mathrm{MA}]$ & 52.34 & 56.96 & 59.31 & 79.55 & -0.44 & 82.67 & 89.03 & 89.21 & 55.31 & -0.46 & 95.19 & 100.92 & 105.21 & 88.14 & -0.61 \\
\hline$\left[\mathrm{MAH}_{-1}\right]$ & 35.46 & 39.35 & 40.50 & 63.72 & -0.33 & 52.56 & 66.62 & 66.00 & 237.71 & -0.97 & & & & & \\
\hline$\left[\mathrm{MA}_{2}\right]$ & 109.22 & 116.01 & 118.26 & 67.46 & -0.59 & 135.76 & 143.45 & 142.03 & 7.65 & -0.48 & & & & & \\
\hline$\left[\mathrm{MA}_{2} \mathrm{H}_{-2}\right]$ & 37.35 & 44.82 & 48.99 & 181.30 & -0.73 & & & & & & & & & & \\
\hline$\left[\mathrm{MA}_{2} \mathrm{H}_{-3}\right]$ & -26.53 & -17.51 & -9.43 & 333.89 & -1.20 & & & & & & & & & & \\
\hline$\left[\mathrm{MA}_{3}\right]$ & 157.48 & 168.38 & 170.82 & 109.24 & -0.89 & & & & & & & & & & \\
\hline
\end{tabular}

${ }^{a} \Delta G, \Delta H$, and $\Delta S$ have the units of $\mathrm{kJ} \mathrm{mol}^{-1}, \mathrm{~kJ} \mathrm{~mol}^{-1}$ and $\mathrm{kJ} \mathrm{mol}{ }^{-1} \mathrm{~K}^{-1}$, respectively. The charge of each species is omitted for simplification. $\mathrm{M}$ indicates the Fe(III) ion, A indicates the ligand Gly or Pro-Hyp or Gly-Pro-Hyp, $\mathrm{H}$ indicates the proton, the negative value of $\mathrm{H}$ indicates the hydroxide ion.

possibly due to their larger structures. In general, the $\log \beta$ values of the complexes increased as the temperature increased. This phenomenon was observed because at a higher temperature, the energy required to trigger the deprotonation of the ligand is also high. Since the deprotonation of the ligands occurred promptly at a higher temperature, the ligands tended to interact with the metal ion having an opposite charge.

\section{Species distribution of the complex}

The $\log \beta$ values of Gly, Pro-Hyp and Gly-Pro-Hyp at $I=0.15 \mathrm{~mol}$ $\mathrm{dm}^{-3} \mathrm{NaCl}$ and at different temperatures were introduced to the HySS2009 program $^{20}$ to simulate the speciation diagrams that could be used to depict the distributions of various complex species at the observed $\mathrm{pH}$ ranges (Fig. 3). It was clear that the amount of free metal ions decreased with the increasing $\mathrm{pH}$ since the metal ions formed complexes with the ligand. These results also showed that $\mathrm{pH}$ affected the type of the complex.

It is shown in Fig. 2(a)-(c) that the $\left[\mathrm{MA}_{3}\right]$ complexes of Gly system were formed between $\mathrm{pH} 4$ and 9. At a lower $\mathrm{pH}$, the $\left[\mathrm{MA}_{2}\right]$ species were found to be more abundant, which indicated that these species were more stable at a lower $\mathrm{pH}$. The [MA] and $\left[\mathrm{MAH}_{-2}\right]$ complexes were also formed at low $\mathrm{pH}$ values, which was in accordance with results reported by Djurdievic regarding iron(III) ion and glycine complexation in a nitrate medium. ${ }^{28}$ Above $\mathrm{pH} 9$, the amount of $\left[\mathrm{MA}_{2} \mathrm{H}_{-2}\right]$ complex increased. As for the Pro-Hyp system, as shown in Fig. 2(d)-(f), [ $\left.\mathrm{MA}_{3}\right]$ was also the most stable species in the $\mathrm{pH}$ range from 6 to 9.5; this was in accordance with the result obtained by Yakubov et al. who used the ligands glycine, di-glycine and tri-glycine. ${ }^{24}$ Above $\mathrm{pH}$ 9.5, the $\left[\mathrm{MA}_{2} \mathrm{H}_{-2}\right]$ complex was formed more, whereas at $\mathrm{pH}$ less than 6 , the complexes of [MA] and $\left[\mathrm{MA}_{2}\right]$ were found to be more abundant. In the Gly-Pro-Hyp system (Fig. 2(g)-(i)), the species distribution was more complex than those of the Gly system and the Pro-Hyp system. This was because Gly-Pro-Hyp had more amino acid residues and more groups, which were able to form chelate complexes. The complexes of Gly-Pro-Hyp, namely, $\left[\mathrm{MA}_{2} \mathrm{H}_{-1}\right],\left[\mathrm{MA}_{2} \mathrm{H}_{-2}\right]$ and $\left[\mathrm{MAH}_{-3}\right]$ were found to contain more hydroxide ions; this might have occurred because Gly-Pro-Hyp was too large to form a stable $\left[\mathrm{MA}_{3}\right]$ complex even though GlyPro-Hyp could chelate with iron stably. The $-\mathrm{OH}$ group could replace Gly-Pro-Hyp and form stable $\left[\mathrm{MA}_{2} \mathrm{H}_{-1}\right]$, $\left[\mathrm{MA}_{2} \mathrm{H}_{-2}\right]$ and $\left[\mathrm{MAH}_{-3}\right]$ structures; this is similar to the formation of $\left[\mathrm{MA}_{2} \mathrm{H}_{-1}\right]$ and $\left[\mathrm{MA}_{2} \mathrm{H}_{-2}\right]$ at $I=0.1$ and $1.0 \mathrm{~mol} \mathrm{dm}^{-3}$ and at $25 \pm 0.1^{\circ} \mathrm{C}$ in which $\mathrm{M}=$ iron(III) and $\mathrm{A}=$ GLDA or HIDS. ${ }^{27}$ The same trend was followed by the iron complex with Gly-Gly-Gly ${ }^{24}$ as well as the iron complexes with L-norleucine and gallic acid. ${ }^{26}$

\section{Thermodynamic properties and the possible structure of the complex}

Thermodynamic properties such as Gibbs free energy $(\Delta G)$, enthalpy $(\Delta H)$ and entropy $(\Delta S)$ provide significant information related to the complex. Thermodynamic properties of the complexes of Gly, Pro-Hyp and Gly-Pro-Hyp against Fe(III) are given in Table 3. Negative values of $\Delta G$ of the complexes indicated that the complex formation was spontaneous. However, for several species, $\Delta G$ was found to have positive values. This was because the structures of the complexes were more complicated since they were formed with more ligands and protons or hydroxides; therefore, more energy was needed for their formation. As the temperature increased, $\Delta G$ was found to be more negative, indicating that the complex formation was more favourable at a higher temperature. At a higher temperature, the ligand and the metal ion move faster than that at a lower temperature; this promotes the interaction of the two molecules and benefits the formation of the complexes. The values of $\Delta H$ for all the complex species were found to be positive, indicating that the complex formation was endothermic. However, [MAH], $\left[\mathrm{MAH}_{-1}\right]$ and $\left[\mathrm{MA}_{2}\right]$ had negative $\Delta H$ values, which indicated that their complex formations were exothermic. All $\Delta S$ values were negative, indicating that the complex formation was reversible.

We also predicted the possible structures of $\left[\mathrm{MA}_{n} \mathrm{H}_{m}\right]$ (Fig. 3) with the ligand Gly-Pro-Hyp as an example. The complex contained the ligands and ferric ions. Some complexes also contained - $\mathrm{OH}$ groups in their structures. In a basic environment, the complex had no- $\mathrm{OH}$ groups. As the $\mathrm{pH}$ decreased, the $-\mathrm{OH}$ 

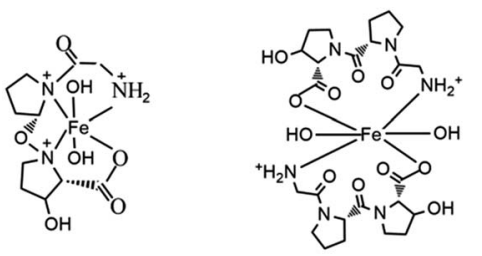

MA

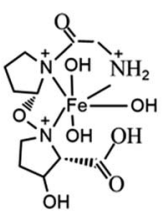

$\mathrm{MAH}_{-1}$

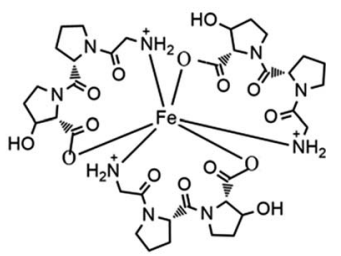

$\mathrm{MA}_{3}$

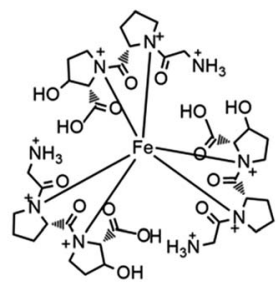

$\mathrm{MA}_{3} \mathrm{H}_{-3}$
Fig. 3 The possible structures of $\left[\mathrm{MA}_{n} \mathrm{H}_{m}\right]$. M indicates the Fe(III) ion, A indicates the ligand Gly-Pro-Hyp.

groups participated in the formation of the complexes. However, it was inconvenient for a $\left[\mathrm{MA}_{3} \mathrm{H}_{m}\right]$ complex to have -OH groups in its structure. Thus, the complexes formed with $-\mathrm{OH}$ groups were $\left[\mathrm{MAH}_{m}\right]$ or $\left[\mathrm{MA}_{2} \mathrm{H}_{m}\right]$.

\section{Conclusions}

The chelate complexes of iron(III) with Gly, Pro-Hyp or Gly-ProHyp have been determined potentiometrically at $I=0.15 \mathrm{~mol}$ $\mathrm{dm}^{-3} \mathrm{NaCl}$ and at temperatures of $25{ }^{\circ} \mathrm{C}, 37^{\circ} \mathrm{C}$, and $40{ }^{\circ} \mathrm{C}$. The complexes formed with Gly-Pro-Hyp as the ligand are more stable than those formed with Pro-Hyp and Gly. The formation of complexes is more favourable at a higher temperature. The chelation abilities of Gly, Pro-Hyp and Gly-Pro-Hyp may contribute to the promotion of iron absorption, and these ligands can potentially reduce the toxicity of free $\mathrm{Fe}(\mathrm{III})$ ion in the body. Besides, the values of $\log \beta$ of the complexes provide basic information regarding the chelating abilities of the ligands Gly, Pro-Hyp, and Gly-Pro-Hyp with Fe(III).

\section{Conflicts of interest}

There are no conflicts to declare.

\section{Acknowledgements}

This research is supported by the Science and Technology Project of Zhejiang Province, China [grant number 2016C32064] and Zhejiang Provincial Natural Science Foundation of China [grant number YL18C200001].

\section{References}

1 S. Ghasemi, A. H. Khoshgoftarmanesh, H. Hadadzadeh and M. Jafari, J. Plant Growth Regul., 2012, 31, 498-508.

2 R. Martorell, J. Nutr., 2002, 132, 875-879.
3 H. Pan, S. Song, Q. Ma, H. Wei, D. Ren and J. Lu, Food Technol. Biotechnol., 2016, 54, 164-171.

4 L. Wang, Y. Pan, Z.-H. Yuan, H. Zhang, B.-Y. Peng, F.-F. Wang and W. Qian, Pathogens, 2016, 12, e1006133.

5 Y. Li, J. Han and G. Huang, Nutrients, 2017, 9, 609-627.

6 Q. Chen, L. Guo, F. Du, T. Chen, H. Hou and B. Li, Int. J. Food Sci. Technol., 2017, 52, 1283-1290.

7 C. Y. Huang, C.-H. Wu, J.-I. Yang, Y.-H. Li and J.-M. Kuo, J. Food Drug Anal., 2015, 23, 671-678.

8 R. E. Cian, A. G. Garzón, D. B. Ancona, L. C. Guerrero and S. R. Drago, Plant Foods Hum. Nutr., 2016, 71, 1-6.

9 S. Na, P. Cui, Z. Jin, H. Wu, Y. Wang and S. Lin, Food Chem., 2017, 230, 627-636.

10 P. Banerjee, L. Suguna and C. Shanthi, Amino Acids, 2015, 47, 317-328.

11 S. Isaka, A. Somova, S. Nakamura, K. Naito, M. Nozawa, N. Inoue, F. Sugihara, I. Nagaoka and K. Kaneko, Exp. Ther. Med., 2017, 13, 2699-2706.

12 W. S. L. Sinaga, Master, Peptides hydrolysate derived from collagen of snakehead murrel (Channa striata) skin demonstrate anti-oxidant and anti-cholesterol activities, Bogor Agricultural University, 2015.

13 A. Baehaki, M. T. Suhartono, N. Sukarno, D. Syah and S. Setyahadi, Res. J. Pharm., Biol. Chem. Sci., 2016, 2016, 1994-2000.

14 S. Yamamoto, K. Deguchi, M. Onuma, N. Numata and Y. Sakai, Biol. Pharm. Bull., 2016, 39, 428-434.

15 M. K. Gordon and R. A. Hahn, Cell Tissue Res., 2010, 339, 247-257.

16 T. T. Nguyen, S. P. Santoso, T. T. Nguyen, A. E. Angkawijaya, P. L. Tran-Nguyen and Y. H. Ju, Chem. Pharm. Bull., 2016, 64, 1560-1569.

17 J. Torres, V. Pintos, S. Domínguez, C. Kremer and E. Kremer, J. Solution Chem., 2010, 39, 1-10.

18 M. Y. Hamed, J. Silver and M. T. Wilson, Inorg. Chim. Acta, 1984, 15, 115-122.

19 P. Gans, A. Sabatini and A. Vacca, Talanta, 1996, 43, 17391753.

20 L. Alderighi, P. Gans, A. Ienco, D. Peters, A. Sabatini and A. Vacca, Coord. Chem. Rev., 1999, 184, 311-318.

21 A. Gergely, I. Sóvágó, I. Nagypaál and R. Király, Inorg. Chim. Acta, 1972, 6, 435-439.

22 A. E. Angkawijaya, A. E. Fazary, S. Ismadji and Y. H. Ju, J. Chem. Eng. Data, 2012, 57, 3443-3451.

23 S. J. Zhu and C. F. Xu, Biochemistry, Higher Education Press, China, Beijing, 2016.

24 K. M. Yakubov, G. M. Vinnichenko, E. Y. Offengenden and A. N. Astanina, Inorg. Chim. Acta, 1983, 79, 273-274.

25 A. E. Angkawijaya, A. E. Fazary, E. Hernowo, M. Taha and Y. H. Ju, J. Chem. Eng. Data, 2011, 56, 532-540.

26 A. E. Fazary, E. Hernowo, A. E. Angkawijaya, T. C. Chou, C. H. Lin, M. Taha and Y. H. Ju, J. Solution Chem., 2011, 40, 1965-1986.

27 Z. A. Begum, I. M. M. Rahman, H. Sawai, Y. Tate, T. Maki and H. Hasegawa, J. Chem. Eng. Data, 2014, 57, 2723-2732.

28 P. Djurdjevic, Transition Met. Chem., 1990, 15, 345-350. 